\title{
Multiple pulmonary contusions in a collegiate football player
}

\author{
Michael Phy DO
}

\begin{abstract}
Pulmonary contusion is an infrequently reported event in contact sports. To date, there are only four reported cases in football players in the literature. This case is unique in its presentation (large contusion, coup/contrecoup injuries) and management (need for air transport shortly after the injury, persistent symptoms, delayed recovery and return to play). Clinical signs and symptoms, such as dyspnea, hemoptysis, and chest wall pain, should increase the suspicion for possible pulmonary contusion. Early imaging with computed tomography (CT) is preferred due to its superior sensitivity and specificity (compared to chest radiography) in detecting pulmonary contusions. In addition, CT scans can quantify the amount of lung damage which can be used in treatment decisions and prognosis. Treatment requires close monitoring and management of frequently associated pulmonary symptoms, such as chest wall pain and hypoxia.
\end{abstract}

Key words: Pulmonary contusion, football, hemoptysis

\section{INTRODUCTION}

This is an uncommon case of a college football player who sustained moderate-sized pulmonary contusions with unique features of coup/contrecoup lesions. The diagnosis of pulmonary contusion is usually made on clinical symptoms of dyspnea, hemoptysis, and chest wall pain. If available, computed tomography (CT) is the preferred method of confirmation. Treatment is supportive and depends on the extent of the injury.

\section{Case Presenttion}

A 19-year-old previously healthy, non-smoking collegiate football player was involved in a hel-

Corresponding author: Michael Phy DO

Contact Information: Michael.phy@ttuhsc.edu

DOI: 10.12746/swrccc2014.0208.107 met-to-chest collision during a game. He collapsed to the ground after impact. It was apparent during his on field assessment that he was having trouble getting his breath. His breathing improved in a very short time, and he walked off the field under his own power. On the sideline he did not complain of shortness of breath, chest pain, headache, or any other symptom. He was removed from competition and taken to the locker room for more comprehensive evaluation. He was not in distress. Initial vital signs were BP 131/66 $\mathrm{mmHg}$ and HR $80 \mathrm{bpm}$; pulse oximetry showed an oxygen saturation of $96 \%$ on room air. Examination of the chest and abdomen revealed no chest wall or abdominal tenderness; there were no abnormal heart or breath sounds on auscultation. When the athlete returned to the sideline, he had bright red hemoptysis (estimated volume $5 \mathrm{ml}$ ).

He was taken for chest $\mathrm{x}$-ray $(\mathrm{CXR})$ at the 
stadium. During the radiographs he had four more episodes of hemoptysis, and he started to complain of some mild restriction in his breathing and increased pain over the right anterior chest wall. The films showed a hazy opacification in the right lower lung field consistent with a pulmonary contusion and no evidence of pneumothorax (Figure 1). He was cleared to make a 90 minute flight back to campus. He was monitored on the flight and had no worsening of symptoms. On arrival, he was admitted to the local medical center for precautionary observation to the general medical floor. The time elapsed from initial injury to admission was four hours. ACT of the chest revealed multiple "ground glass opacities suggestive of contusions" in the right lung. The largest involvement was seen in the right anterior segments and a smaller contrecoup contusion was noted in the right posterior lung fields (Figure 2). The contusion was seen over 26 cuts $(13 \mathrm{~cm})$ and involved $20 \%$ volume of the right lung (calculation by interpreting radiologist). Repeat examination revealed new, prominent inspiratory crackles in the right anterior lung fields. There was definite point tenderness in the right lower anterior chest wall as well. He had no increase in symptoms overnight. Oxygen saturations were $96 \%$ or higher on room air. He still had intermittent hemoptysis on the morning of discharge.

He began some very low intensity cardioworkouts on day two post-injury. This was increased as tolerated over the next four days. Hemoptysis cleared on day four post injury. He was not cleared to play in the next game due to some mild dyspnea. He returned to full unrestricted activity, including contact nine days after the injury. He had no further sequelae and competed in the remainder of the games that season. No follow up imaging was obtained.

\section{Discussion}

Pulmonary contusion in contact sports is rarely reported, and to date there are only four reports in the medical literature, all involving football players (Table). ${ }^{1-3}$ It is the most common injury associated with

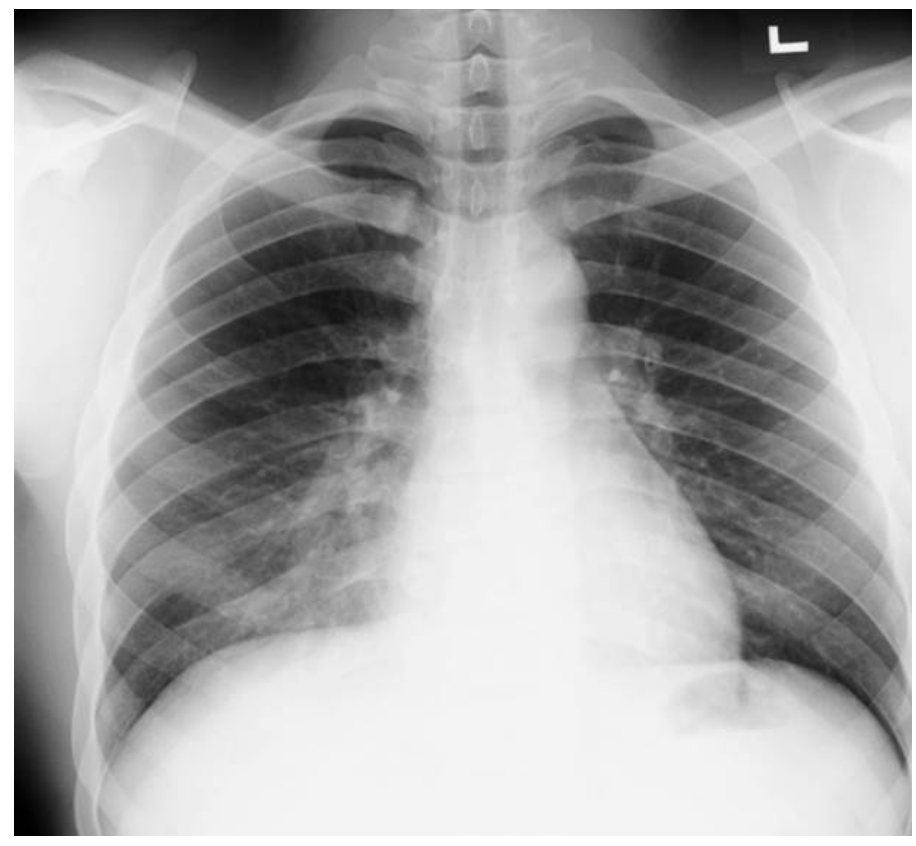

Figure 1. Initial chest radiograph showing right lower lobe density

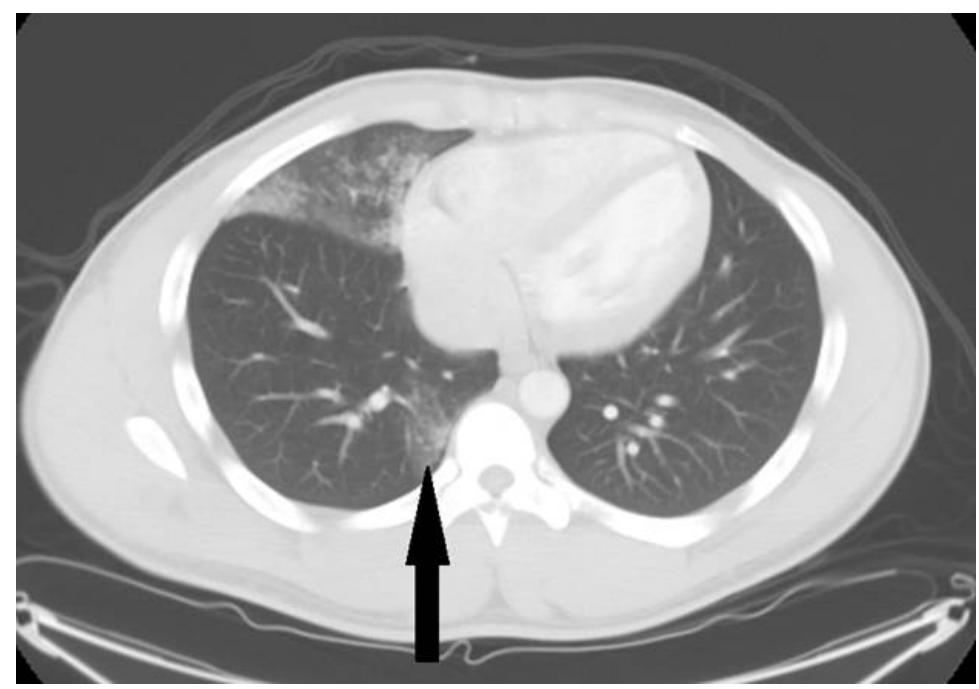

Figure 2. CT of the chest showing dense infiltrate in the right anterior lung field and a contrecoup lesion (arrow) in the right posterior lung field consistent with pulmonary contusions. 
blunt chest trauma. ${ }^{4}$ The few reports in contact sports are surprising considering the number of participants and may reflect either under-reporting or underdiagnosis. The predominant mechanism of injury in civilians involves rapid deceleration after motor vehicle accidents or falls. ${ }^{5}$ The pathology of the contused lung is characterized by parenchymal hemorrhage, interstitial edema, and alveolar collapse or rupture. This injury can lead to pathophysiologic changes, depending on the extent of the injury, including bronchospasm and alveolar dysfunction. Large hemorrhages from contusions may lead to ventilation/perfusion mismatch, pulmonary edema, and decreased lung compliance.

Clinically recognized symptoms are not always immediate and may be delayed for many hours; they usually resolve within seven days. The typical presentation includes chest pain and increased work of breathing. Associated physical findings may include hemoptysis, tachypnea, crackles, and wheezing. ${ }^{8}$ Chest radiography is usually the initial diagnostic test and abnormal findings include focal or diffuse opacification or consolidation extending beyond lung segments or lobes. ${ }^{8,9}$ However, the lack of abnormal findings should not reduce diagnostic suspicion, as CXR abnormalities may be absent in $47 \%$ of cases at the time of admission ${ }^{10}$ and absent altogether in $10-36 \%$ of cases. ${ }^{11}$ CT scans have superior sensitivity and specificity for detecting pulmonary contusions compared to CXRs. ${ }^{2,11}$ The additional value of CT imaging includes its ability to quantify the amount of damaged lung tissue and the inclusion of ribs, chest wall, and other thoracic structures that could also be injured (aorta, vena cava, thoracic duct, pericardium, pneumothorax, etc.). CT imaging may also help with clinical prognosis. Studies have demonstrated that the amount of injured lung volume predicts the need for mechanical ventilation ( $>28 \%$ lung volume $)^{9,12}$ and the development of acute respiratory distress syndrome (>20\% lung volume). ${ }^{4,13}$

The management of pulmonary contusion is supportive and depends on the extent of the injury. A typical management strategy should include supple- mental oxygen in cases of hypoxemia and aggressive lung expansion maneuvers. Control of chest wall pain is extremely important to improve impaired pulmonary mechanics and decrease the chance of developing hypoventilation, atelectasis, pneumonia, or worsening respiratory function. ${ }^{8}$ Currently there are no studies that support the use of prophylactic antibiotics or corticosteroids after pulmonary contusion. Although there are risks for long term sequelae, none have been reported in the cases in which the pulmonary contusion happened as the result of an athletic injury.

Pulmonary contusion at an athletic event can add another layer of complexity if the injury occurs at an away venue. The decision to transport patients home should be made on an individual basis taking into account the severity of presenting signs and symptoms, the mode of travel, and the medical services that can be provided during that time. In our case, the injury occurred at an away venue. Transportation required a one hour bus ride followed by a 90 minute airplane ride. The athlete had stable vital signs, normal oxygenation, and no clinical deterioration since the initial injury, so the decision was made to proceed with transport. During that transit, we were able to monitor clinical symptoms and pulse oximetry. We arranged for portable oxygen to be available on the flight, but it was not needed.

In the case of athletes, there are no evidence based guidelines for return to play in these types of injuries. The characteristics of this injury in football players are summarized in the Table. In all of the previously reported cases in football players, the athlete was able to return to participation after a few days, and all participated in the team's next game. Our case is different from previously reported cases due to the multiple contusions, the total percentage of lung involved, and the persistent hemoptysis and dyspnea. The athlete's return to play was predicated on resolution of symptoms and did not allow for the return to full activity for nine days. 
Table: Characteristics of Pulmonary Contusion in Football Players

\begin{tabular}{|c|c|c|c|c|c|c|c|c|}
\hline Case & Age & $\begin{array}{l}\text { Type of Col- } \\
\text { lision }\end{array}$ & Initial Symptoms & CXR Findings & $\begin{array}{l}\text { CT Chest Find- } \\
\text { ings }\end{array}$ & Management & $\begin{array}{l}\text { Resolution } \\
\text { of Symp- } \\
\text { toms }\end{array}$ & $\begin{array}{l}\text { Return to } \\
\text { Play }\end{array}$ \\
\hline Lively & 22 & $\begin{array}{l}\text { Anterior chest } \\
\text { wall }\end{array}$ & $\begin{array}{l}\text { Immediate onset } \\
\text { of SOB, hemop- } \\
\text { tysis }\end{array}$ & No abnormalities & $\begin{array}{l}\text { Opacification in } \\
\text { periphery of right } \\
\text { upper lobe }\end{array}$ & $\begin{array}{l}\text { Rest and ob- } \\
\text { servation }\end{array}$ & 20 minutes & 2 days \\
\hline Lively & 23 & $\begin{array}{l}\text { Hit in left } \\
\text { chest wall, } \\
\text { fell on ball on } \\
\text { his right chest }\end{array}$ & $\begin{array}{l}\text { Immediate onset } \\
\text { of chest pain, } \\
\text { hemoptysis }\end{array}$ & No abnormalities & $\begin{array}{l}\text { Pulmonary con- } \\
\text { tusion right upper } \\
\text { lobe }\end{array}$ & $\begin{array}{l}\text { Rest and ob- } \\
\text { servation }\end{array}$ & Minutes & 3 days \\
\hline Gillespie & 22 & $\begin{array}{l}\text { Blows to } \\
\text { chest }\end{array}$ & $\begin{array}{l}\text { Immediate onset } \\
\text { of SOB, hemop- } \\
\text { tysis }\end{array}$ & No abnormalities & $\begin{array}{l}\text { Bilateral pulmo- } \\
\text { nary contusions } \\
\text { in the upper } \\
\text { lobes, lingula, } \\
\text { and right middle } \\
\text { lobe }\end{array}$ & $\begin{array}{l}\text { Rest and ob- } \\
\text { servation }\end{array}$ & $2-3$ hours & 4 days \\
\hline Meese & 19 & $\begin{array}{l}\text { Blow to left } \\
\text { posterior } \\
\text { lateral chest } \\
\text { wall }\end{array}$ & $\begin{array}{l}\text { Day after injury } \\
\text { reported severe } \\
\text { left sided chest, } \\
\text { flank, and } \\
\text { abdominal pain, } \\
\text { hemoptysis }\end{array}$ & No abnormalities & $\begin{array}{l}\text { Consolidation of } \\
\text { left lower lung } \\
\text { parenchyma with } \\
\text { mild atelectasis } \\
\text { and pleural ef- } \\
\text { fusion }\end{array}$ & $\begin{array}{l}\text { Rest and ob- } \\
\text { servation }\end{array}$ & 7 days & $\begin{array}{l}\text { several } \\
\text { days }\end{array}$ \\
\hline Phy & 19 & $\begin{array}{l}\text { Blow to right } \\
\text { anterior chest } \\
\text { wall }\end{array}$ & $\begin{array}{l}\sim 20 \text { minutes, } \\
\text { hemoptysis and } \\
\text { SOB }\end{array}$ & $\begin{array}{l}\text { Hazy opacifica- } \\
\text { tion of right lower } \\
\text { lung }\end{array}$ & $\begin{array}{l}\text { Multiple ground } \\
\text { glass opacities } \\
\text { in the right lung } \\
\text { with contrecoup } \\
\text { lesion in right } \\
\text { posterior lung }\end{array}$ & $\begin{array}{l}\text { Rest and ob- } \\
\text { servation }\end{array}$ & 5 days & 9 days \\
\hline
\end{tabular}

\section{ConcLusion}

This is a case of pulmonary contusion in a football player that is different from the four previously reported cases. The unique features in our case include multiple contusions, coup/contrecoup lesions, and a significant amount of involved lung volume $(\sim 20 \%)$. The need to travel and fly home added a level of medical complexity that has not been reported. This athlete's symptoms lasted longer, and his return to unrestricted activity was delayed. Similar to the other reported cases, he recovered with supportive care. Despite the number of collisions in football, pulmonary contusion remains a rarely reported event. Team physicians are encouraged to consider this diagnosis when athletes report chest wall pain, dyspnea, and/or hemoptysis. Additional reports of cases will help delineate the severity of injuries, treatments, and possible return to play protocols. 
Author Affiliation: Michael Phy is a general internist in the Department of Internal Medicine at Texas Tech University Health Science Center in Lubbock, TX and a team physician at Texas Tech University.

Received: 08/05/2014

Accepted: $10 / 02 / 2014$

Reviewers: Anoop Nambiar MD

Published electronically: 10/15/2014

Conflict of Interest Disclosures: none
13. Wang $\mathrm{S}$, Ruan Z, Zhang J et al. The value of pulmonary contusion volume measurement with three-dimensional computed tomography in predicting acute respiratory distress syndrome development. Ann Thor Surg 2011; 92:1977-83.

\section{REFERENCES}

1. Meese MA, Sebastianelli WJ. Pulmonary Contusion Secondary to Blunt Trauma in a Collegiate Football Player. Clin J Sport Med 1997; 7:309-10.

2. Lively MW, Stone D. Pulmonary Contusion in Football Players. Clin J Sport Med 2006; 16:177-178.

3. Gillespie H, Sisson R, DiFiori, JP. Pulmonary Contusion in a Football Player. Curr Sport Med Rep 2013; 12(2):57-58.

4. Miller PR, Croce MA, Bee TK, et al. ARDS after pulmonary contusion: accurate measurement of contusion volume identifies high-risk patients. J Trauma 1997; 42:973-9.

5. O'Connor JV, Kufera JA, Kerns TJ, et al. Crash and occupant predictors of pulmonary contusion. J Trauma 2009; 66:1091-95. 6. Demling RH, Pomfret EA. Blunt chest trauma. New Horiz 1993; 1:402-21.

7. Oppenheimer L, Craven KD, Forkert L, et al. Pathophysiology of pulmonary contusion in dogs. J Appl Physiol 1979; 47:718-28.

8. Cohn SM, DuBose JJ. Pulmonary Contusion: An update on recent advances in clinical management. World J Surg 2010; 34:1959-70.

9. Wanek S, Mayberry JC. Blunt thoracic trauma: flail chest, pulmonary contusion and blast injury. Crit Care Clin 2004; 20:7181.

10. Pape HC, Remmers D, Rice J, et al. Appraisal of early evaluation of blunt chest trauma: development of a standardized scoring system for initial clinical decision making. J Trauma 2000; 49:496-504.

11. Felden J. Closed lung trauma. Clin Sports Med 2013; 32:25565.

12. Wagner RB, Jamieson PM. Pulmonary contusion. Evaluation and classification by computed tomography. Surg Clin North Am 1989; 69:31-40. 